\title{
EFFECTS OF VITAMINS C AND E ON ERYTHROCYTES AND BLOOD CHEMISTRY PROFILE OF SHIKA BROWN LAYER HENS TRANSPORTED BY ROAD
}

\author{
J.J. AJAKAIYe ${ }^{*}$; J.O. AYO² and D. MuSa ${ }^{3}$ \\ 1 jojagrovet@yahoo.com *Corresponding author's current mailing address (Correo vigente) \\ College of Agriculture and Animal Science, Ahmadu Bello University, Kaduna, NIGERIA. \\ Universidad Central de Las Villas, Km 3.5 Carretera Camajuani, Código Postal 54830, Santa Clara, \\ CUBA. E-mail: joachim@uclv.edu.cu \\ 2 Department of Veterinary Physiology and Pharmacology, Faculty of Veterinary Medicine, Ahmadu \\ Bello University, Zaria, NIGERIA. E-mail: ayojo94@yahoo.com \\ ${ }^{3}$ Human Trypanosomiasis Division, Department of Pathology, Nigerian Institute for Trypanosomiasis \\ and Onchocerciasis Research, \# 1 Surame Road, Kaduna, NIGERIA. E-mail: musakaus@yahoo.com
}

\begin{abstract}
Ajakaiye, J.J., J.O. Ayo \& D. Musa. 2010. Effects of vitamins C and E on erythrocytes and blood chemistry profile of shika brown layer hens transported by road. Acta Zool. Mex. (n. s.), 26(3): 527-537.
\end{abstract}

ABSTRACT. This study was conducted to determine the effects of dietary supplementation of vitamin C (1- ascorbic acid) and vitamin E (dl- - -tocopherol acetate) on some erythrocytes and blood chemistry parameters of laying hens transported during hot-dry season. Ninety, 22 weeks old indigenous hybrid Shika Brown layer (SBL) hens were randomly divided into three groups of 30 each, and three replicates of 10 birds within each group. The first group was administered vitamin $\mathrm{C}$ at a dosage $200 \mathrm{mg} / \mathrm{kg}$ of bodyweight dissolved in $5 \mathrm{ml}$ of sterile water $\mathrm{w} / \mathrm{v}$, the second group was administered vitamin $\mathrm{E}$ at a dosage $200 \mathrm{mg} / \mathrm{kg}$ of bodyweight dissolved in $5 \mathrm{ml}$ edible vegetable oil $\mathrm{w} / \mathrm{v}$, while the third group was administered $5 \mathrm{ml}$ sterile water (control) v/v only. All administration was through the oral route. All groups were fed basal diet pre- and post experiment. Just before transportation, food and water were withdrawn. Post-transportation, hemoglobin $\left(\mathrm{H}_{\mathrm{b}}\right)$, packed cell volume $(\mathrm{PCV})$ and blood platelets concentrations were significantly $(\mathrm{P}<0.01)$ and $(\mathrm{P}<0.001)$ reduced in vitamin $\mathrm{C}$ treated group; vitamin $\mathrm{E}$ and control groups compared with pre-transportation values respectively. However, posttransportation value of red blood cell $(\mathrm{RBC})$ was only significantly $(\mathrm{P}<0.05)$ reduced in control group compared with pre-transportation value. Post-transportation blood chemistry concentrations of total protein (TP) and alkaline phosphatase (ALP) were significantly $(\mathrm{P}<0.05)$ and $(\mathrm{P}<0.01)$ reduced in all experimental groups compared with pre-transportation values respectively. However, posttransportation values of creatine phosphokinase (CPK) and aspartate aminotransferase (AST) were significantly $(\mathrm{P}<0.01)$ and $(\mathrm{P}<0.05)$ reduced in vitamins $\mathrm{C}$ and $\mathrm{E}$ groups compared with pretransportation values respectively. It is concluded that the administration of antioxidant vitamins $\mathrm{C}$ and E alleviated the negative effects of stress in birds transported during the hot-dry season.

Keywords: Layer hens, transport stress, vitamins C and E, blood parameters.

Recibido: 01/08/2009; aceptado: 11/06/2010. 
Ajakaiye, J.J., J.O. Ayo \& D. Musa. 2010. Efectos de las vitaminas C y E en los eritrocitos y en el perfil químico sanguíneo de gallinas ponedoras Shika Brown transportadas por carretera. Acta Zool. Mex. (n. s.), 26(3): 527-537.

RESUMEN. Se realizó el trabajo con el objetivo de determinar los efectos de la suplementación alimentaria de las vitaminas C (L-ácido ascórbico) y vitamina E (dl-·-tocoferol) sobre algunos parámetros de eritrocitos y químicos de las aves ponedoras transportado durante la temporada cálida y seca. Se seleccionaron noventa gallinas ponedoras Shika Brown, hibrido indígena de 22 semanas de edad y fueron divididas aleatoriamente en tres grupos de 30 gallinas, y tres réplicas de 10 gallinas dentro de cada grupo. Para el primer grupo, se suministró $200 \mathrm{mg} / \mathrm{kg} /$ peso vivo (pv) de la vitamina C disuelto en $5 \mathrm{ml}$ de agua estéril p/v (peso por volumen), en el segundo grupo se suministró $200 \mathrm{mg} / \mathrm{kg} / \mathrm{pv}$ de la vitamina E disuelto en $5 \mathrm{ml}$ de aceite comestible p/v. Al último grupo (control) se suministró $5 \mathrm{ml}$ de agua estéril v/v. La vía de administración fue oral. Se alimentaron las aves con una dieta basal antes y después del experimento. Alimento y agua fueron retirados antes de la transportación. Después de la transportación, las concentraciones de hemoglobina $\left(\mathrm{H}_{\mathrm{b}}\right)$, hematocrito $(\mathrm{PCV})$ y las plaquetas fueron reducidas $(\mathrm{P}<0.01)$ y $(\mathrm{P}<0.001)$ significativamente en el grupo tratado con vitamina $\mathrm{C}$; y los grupos tratados con vitamina $\mathrm{E}$ y el control en comparación con los valores antes de la transportación respectivamente. Sin embargo, después de la transportación, el valor de la célula roja de la sangre (RBC) solo se redujó $(\mathrm{P}<0.05)$ significativamente en el grupo de control en comparación con su valor antes de la transportación. Las concentraciones de proteínas totales (TP) y fosfatasa alcalina (ALP) después de la transportación fueron reducidas $(\mathrm{P}<0.05)$ and $(\mathrm{P}<0.01)$ significativamente en todos los grupos experimentales en comparación con sus valores antes de la transportación respectivamente. Mientras, después de la transportación, los valores de la creatina fosfokinasa (CPK) y aspartato aminotransferasa (AST) fueron reducidas $(\mathrm{P}<0.01)$ y $(\mathrm{P}<0.05)$ significativamente en los grupos tratados con vitaminas $\mathrm{C}$ y E respectivamente. Se concluyó, que la suplementacion de las vitaminas $\mathrm{C}$ y E como antioxidantes, alivió los efectos negativos del estrés en las aves transportada durante la temporada seca y cálida.

Palabras Claves: Gallina ponedoras, estrés por transportación, vitaminas C y E, parámetros hematológicos

\section{INTRODUCTION}

With the incessant increase in global population and its attendant increase in demand for food, poultry production has continued to expand due to the nutritive and biological values of its products: egg and meat. Commercial layer is a good source of animal protein through the production of eggs and meat as end-of-lay hens that is more affordable compared to the cost of other species in the rural and urban communities in Nigeria (Minka 2005; Oladele \& Ayo 1999). All poultry species and major breeds employed in the main intensive production systems are transported at least twice during their lifetimes over distances that may range from a few kilometers to journeys with durations of many hours. Most journeys are by road e.g. from hatchery to production site or from farm to processing plant but some birds may also be transported by air or sea. All modes of transport involve the placement of birds or chicks into transport containers which are subsequently loaded on to vehicles (Mitchell \& Kettlewell 2009).

The Shika Brown layer (SBL) hen is an indigenous hybrid developed from National Animal Production Research Institute (NAPRI), Shika, Nigeria. The hybrid 
was selected from pure bred Rhodes Island Red (RIR) and Brown Leghorn (BL), they were developed mainly for high production performance and resistance to the prevailing harsh weather conditions in Nigeria (Buvanendran 1979). This breed and numerous others are been transported daily from the northern to the southern part of Nigeria and vice versa, passing through various ecological zones. Kaduna is located in the Northern Guinea Savannah zone of Nigeria; for the purpose of this study, the hot-dry (May) season is recognized.

During transportation the birds are constantly subjected to fluctuations of environmental factors (Minka \& Ayo 2008), which cause pathophysiological changes in their body systems (Donkoh 1989; Larkins 1999). These pathophysiological states in combination with the thermal core within the transporting medium may render the birds more susceptible to thermal stress and may form a part of the transport stress experienced by poultry and lead to increased mortalities during exposure to hostile thermal microenvironments in transit and contribute to the observed increase in transport mortalities seen during challenging meteorological conditions

Whitehead \& Keller (2003); and Minka (2005) reported such negative effects of transportation on some hematological and plasma metabolites parameters of racing pigeons and Red Sokoto Goats (RSG) transported by road.

Likewise, RBC, PCV, $\mathrm{Hb}$ and TP have been shown to be important indices of livestock health and production status (Oyewale \& Fajimi 1988). PCV, mean corpuscular volume (MCV), mean hemoglobin concentration $(\mathrm{MCH})$ and mean corpuscular hematocrit (MCHC) on their own, are reliable index of $\mathrm{Hb}$ and of the number of circulating erythrocytes (Benjamin 1985). While changes in plasma creatine phosphokinase, total protein (TP), and especially of plasma globulin, may reflect the severity of disease process in birds, and thus serve as basis for prognosis (Hawkey et al. 1983; Oladele et al. 2005).

Various solutions to these problems have been suggested such as: improved vehicle and transport containers design, changes in transport practices and procedures, regulation of journey distance and the introduction of genetic breeds that are less susceptible to thermal stress (Nilipour 2002; Vecerek et al. 2006). However, from available literature consulted, there is no information on the use of antioxidants vitamins in transported birds. Antioxidants vitamins such as vitamins $\mathrm{A}, \mathrm{C}$ and $\mathrm{E}$ have been widely documented to alleviate heat stress associated with environmental changes in Japanese quails and laying hens (Sahin et al. 2003; Ciftci et al. 2005).

The aims of this study therefore, were to determine the alleviating effects of the administration of vitamins $\mathrm{C}$ and $\mathrm{E}$ on SBL hens transported during the hot-dry season.

\section{MATERIALS AND METHODS}

Experimental site and meteorological data. The study was conducted in May, corresponding to the hottest month in this region of the world, at the College of 
Agriculture and Animal Science, Ahmadu Bello University, Mando, Kaduna (11\% 10`N, 070 38 E), in the Northern Guinea Savannah zone of Nigeria. Data of precipitation and wind direction were collated from the Meteorological Unit of the Institute for Agricultural Research, Ahmadu Bello University, Samaru, Zaria, Nigeria. The AT and RH inside and outside the pen were recorded daily and for three days before and after the journey period at 07:00, 14:00 and 18:00 h respectively. A standard ambient thermometer for AT and wet and dry-bulb hygrometer for RH were used. The wet and dry bulb values were recorded, and $\mathrm{RH}$ calculated using the depression factor as indicated in the manufacturer's manual. Both instruments from (Cocet, China), were obtained from a commercial medical equipment sales outlet in Kaduna, Nigeria.

Management of birds and Experimental design. Ninety apparently healthy (22 weeks of age; Shika Brown) layer chickens and weighing $1.1 \pm 0.0 \mathrm{Kg}$ were randomly divided into three replicate groups (cells) within each of three treatment groups (pens). For the purpose of homogeneity, each pen containing a particular treatment group was partitioned into three equal cells by $5 \mathrm{~m}$ plywood, so that each replicate cell contained 10 birds at a stocking rate of $0.373 \mathrm{~m}^{2} /$ bird (Koelkebeck \& Cain 1984) throughout the study period. All birds were fed basal layer diet and water was given ad libitum. All necessary medications were administered to the birds. One week to the commencement of the experiment, deep-body temperatures of each bird was recorded daily using a digital thermometer (accuracy $\pm 0.1^{\circ} \mathrm{C}$ ) inserted $5 \mathrm{~cm}$ into mucosal wall of the rectum to ascertain their health status. The birds were also accustomed to the experimental procedures. Food and water were withdrawn just before the journey. On the experimental day and just before loading into the vehicle, the first group were administered orally with vitamin $\mathrm{C}$ at a dosage of $200 \mathrm{mg} / \mathrm{kg}$ body weight dissolved in $5 \mathrm{ml}$ of sterile water $\mathrm{w} / \mathrm{v}$, while the second group were administered orally with vitamin $\mathrm{E}$ at a dosage of $200 \mathrm{mg} / \mathrm{kg}$ body weight dissolved in $5 \mathrm{ml}$ edible vegetable oil w/v and the last group were administered $5 \mathrm{ml}$ sterile water only (control) v/v. Subsequently, the birds were transported by road for $6 \mathrm{~h}$ duration, starting from 09:00-15:00 h. After the journey, the birds were returned to the same pen and kept under the same conditions and fed, as it was done before transportation.

Arrangement of birds, vehicle design and journey time. The birds were easily caught by experts and feather tagged by groups. Thereafter, all groups were uniformly inter-mixed and loaded into nine standard plastic crates at stocking density of $0.0350 \mathrm{~m}^{2} / \mathrm{bird}$ (Delezie et al. 2007). In order to maintain the homogeneous distribution of environment and "thermal core" load within the vehicle, the crates were arranged in groups of three from the front to the rear part of the vehicle. The vehicle used for the journey was a customary 18-seater Toyota Hi-ace bus that had glass louvers for regulating air movement inside the bus. The top roof was made up 
of a metal iron from outside and a stock-pile of heat-absorbable foam materials, covered with thick polythene strap from inside. The floor was made-up of metal, and it was covered with $5 \mathrm{~cm}$ wood shavings. The vehicles traveled on a tarred road for a period of $6 \mathrm{~h}$ at a speed of $50 \mathrm{~km} / \mathrm{h}$. Meteorological data inside and outside the vehicle were recorded during the journey period using standard ambient thermometer for AT and wet and dry-bulb hygrometer for RH. Both instruments used were from (Cocet, China). All measurements were recorded inside and outside the vehicle at 1 , $2,3,4,5$, and finally at $6 \mathrm{~h}$ during the journey period.

Blood analysis. For erythrocytes analysis, $5 \mathrm{ml}$ of blood were obtained from ten birds per group, through venopuncture of brachial vein into previously sterilized test tubes with ethylene diamine tetra acetic acid (EDTA) as anti-coagulant. Each tube was gently mixed by repeated inversion for $2 \mathrm{~min}$. Samples were immediately transferred to the laboratory for analysis. PCV, $\mathrm{H}_{\mathrm{b}}, \mathrm{RBC}$ counts, $\mathrm{MCV}, \mathrm{MCHC}$ and $\mathrm{MCH}$ were calculated from $\mathrm{Hb}, \mathrm{PCV}$ and RBC (Feldman et al. 2000). Blood platelets counts were conducted as described by Wilson (2008).

Samples for blood chemistry, were taken from another ten birds per group, through venopuncture of the brachial vein into previously sterilized test tubes with heparin, gently depositing $5 \mathrm{ml}$ of blood into test tubes, the samples was later centrifuged at $3500 \mathrm{~g}$ for 15 minutes, in order to obtain blood plasma, these were later stored at $-10{ }^{\circ} \mathrm{C}$ until analysis were carried out. Metabolites concentrations were measured spectrophotometrically (Hollands \& Logan 1966), with a biochemical analyzer SP-9 equipment (PYE UNICAM, Germany). Both samples were taken immediately prior to loading into the crate and upon removal after the journey.

Statistical analysis. All data were subjected to student's paired $t$-test. Data were expressed as mean \pm standard error of the mean (mean \pm SEM). Values of $(\mathrm{P}<0.05)$ were considered significant.

\section{RESULTS}

The ambient temperature (AT) and relative humidity (RH) of $27.2 \pm 1.2-29.3$ $\pm 1.8{ }^{\circ} \mathrm{C}$ and $91.2 \pm 5.3 \%$ pre-transportation were not significantly $(\mathrm{P}>0.05)$ different from $27.8 \pm 1.5-29.7 \pm 2.0{ }^{\circ} \mathrm{C}$ and $91.4 \pm 4.3$ obtained posttransportation (table 1).

The hematological parameters are shown in table 2. Post-transportation, $\mathrm{H}_{\mathrm{b}}, \mathrm{PCV}$ and $\mathrm{RBC}$ concentrations were significantly $(\mathrm{P}<0.01)$ and $(\mathrm{P}<0.001)$ reduced in vitamin $\mathrm{C}$ treated group; vitamin $\mathrm{E}$ and control groups compared with pretransportation values respectively. However, post-transportation value of red blood cell $(\mathrm{RBC})$ was only significantly $(\mathrm{P}<0.05)$ reduced in control group compared with pre-transportation value. 


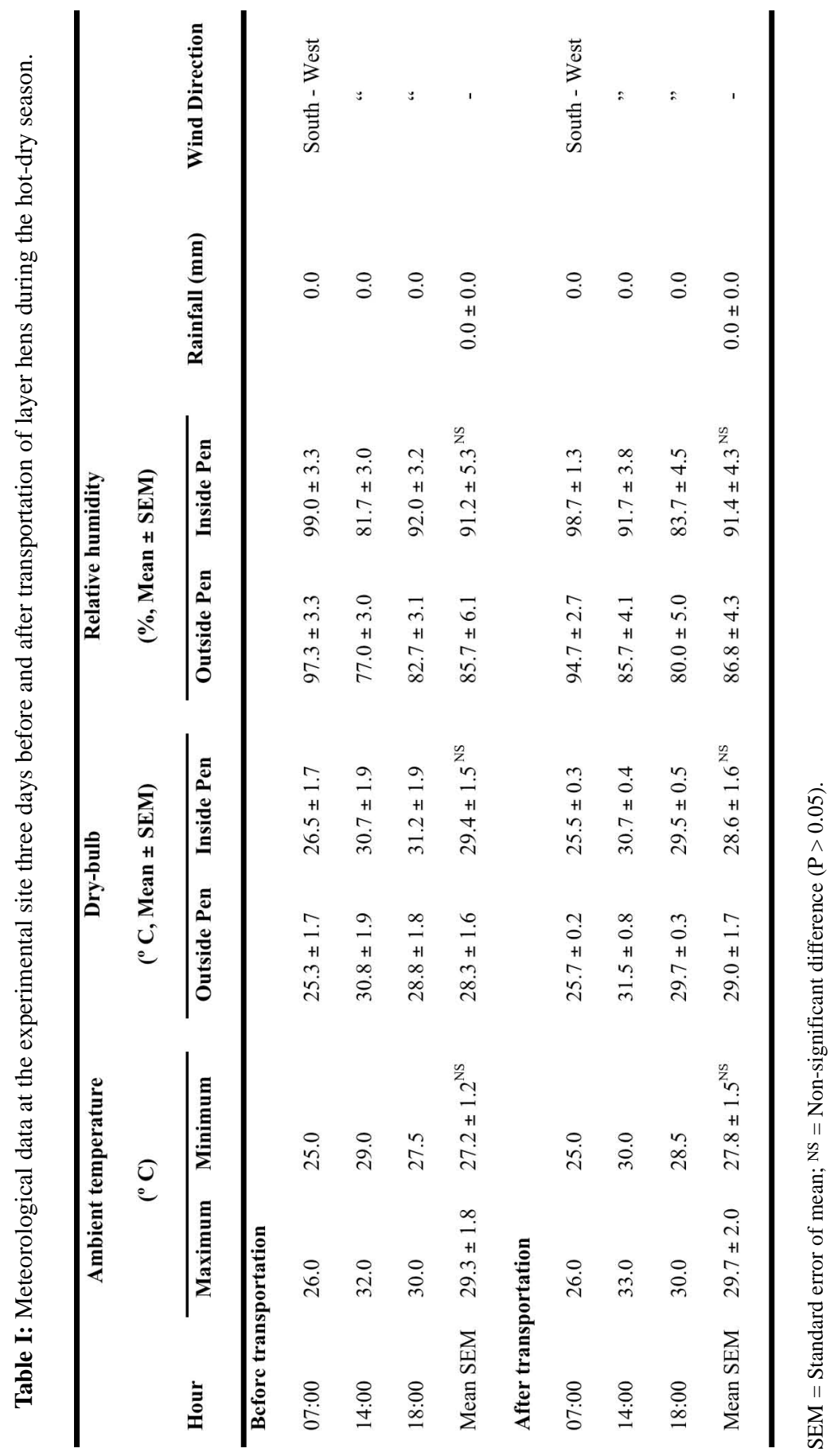



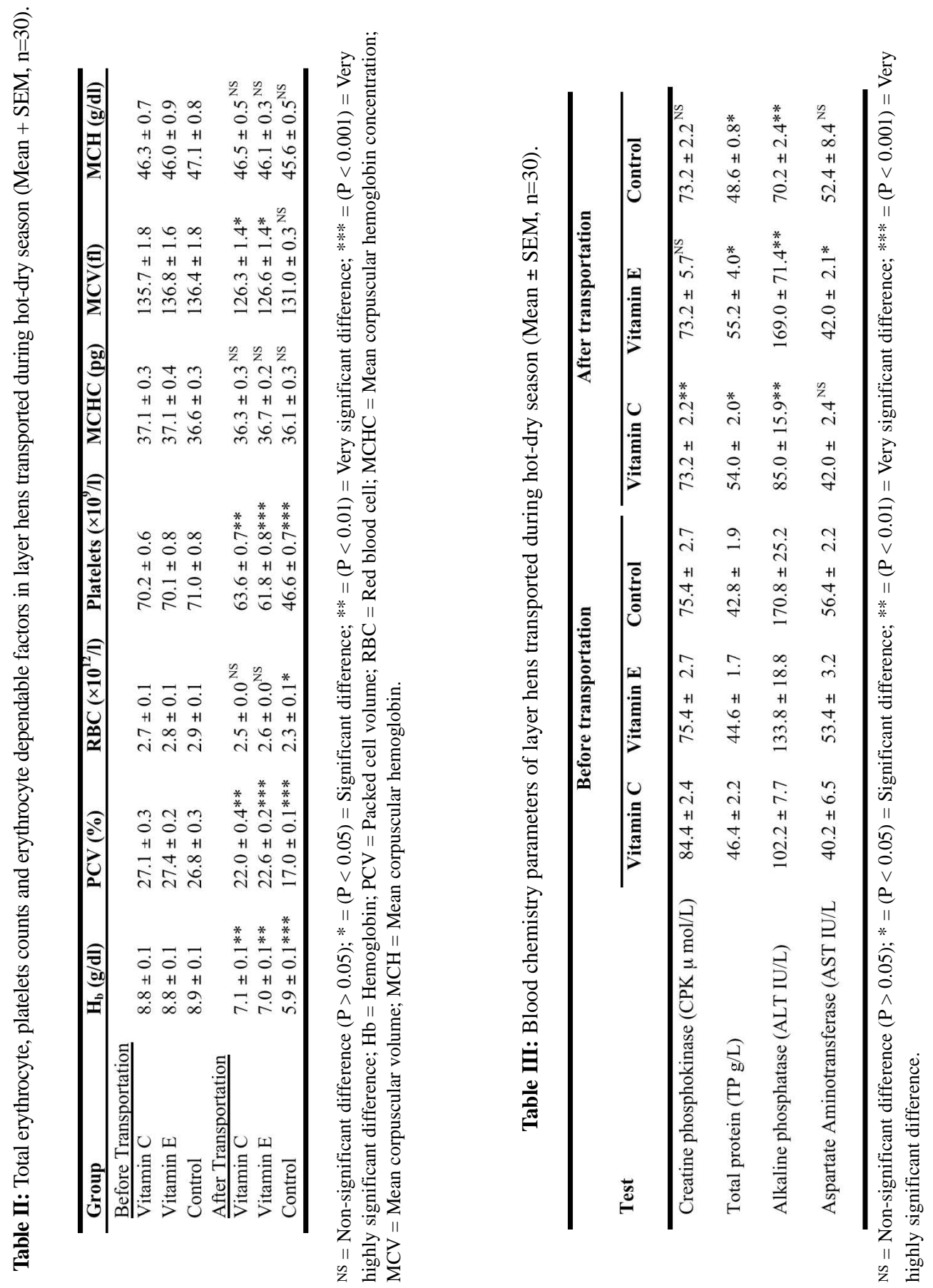
Although the MCHC, MCV and MCH values post-transportation were reduced in all experimental groups, but there were no significant $(\mathrm{P}>0.05)$ differences from those obtained pre-transportation, except $\mathrm{MCV}$ where there was a significant $(\mathrm{P}>$ 0.05 ) difference in vitamins $\mathrm{C}$ and $\mathrm{E}$ treated groups.

In blood clinical chemistries, values analyzed are shown in table 3. Posttransportation blood chemistry concentrations of TP, ALP, CPK and AST were significantly $(\mathrm{P}<0.01)$ and $(\mathrm{P}<0.05)$ reduced in vitamins $\mathrm{C}$ and $\mathrm{E}$ groups compared with pre- transportation values respectively.

\section{DISCUSSION}

The results obtained in the present study showed that the transported hens were subjected to high ambient temperature and relative humidity, characteristic of the late hot-dry season in the Northern Guinea Savannah zone of Nigeria. The high AT values recorded were predominantly outside the established thermoneutral zone for chickens, ranging between $12-24{ }^{\circ} \mathrm{C}$ for birds reared in the temperate region (Selyansky 1975), and $22-28^{\circ} \mathrm{C}$ for tropical region (Holik 2009).The meteorological results demonstrated that transportation of layers during the hot-dry season was thermally stressful to the layers and may impair their homeostatic control mechanisms. Such responses adversely affect health status and productivity of layers (Jindal 1980; West 2003). This result is in agreement with the findings of Igono et al. (1982) and Minka \& Ayo et al. (2009) who reported that the hot-dry season is thermally stressful to transported animals. The decrease observed in the $\mathrm{H}_{\mathrm{b}}, \mathrm{PCV}$ and RBC post-transportation, compared to pre-transportation, were within the normal range for birds especially in the vitamins $\mathrm{C}$ and $\mathrm{E}$ treated groups but outside the range in the control group. The observed reduction in $\mathrm{H}_{\mathrm{b}}, \mathrm{PCV}$ and $\mathrm{RBC}$ demonstrated and suggested an anemic condition in all the experimental birds. This observation is not in agreement with the findings of Singh \& Sirisinghe (2005) on the acute effect of an 18-kilometer run on hematological and plasma electrolyte parameters of human subject under conditions of high ambient temperatures and humidity, who observed a very highly significant $(\mathrm{P}<0.001)$ increases in $\mathrm{PCV}$ and $\mathrm{H}_{\mathrm{b}}$ concentrations. The increase observed in the values of the $\mathrm{H}_{\mathrm{b}}$ and PCV may probably due to moderate level of dehydration; and hence hemoconcentration due to loss of body weight during the run, and fluid shifts from intravascular space.

However, the administration of the antioxidant vitamin $\mathrm{C}$ or $\mathrm{E}$ resulted in the maintenance of RBC counts with the value obtained pre-transportation. The result showed that the vitamins prevented the release of erythrocytes from their pool in the body into the peripheral circulation apparently due to the inhibitory role of vitamin $\mathrm{C}$ on circulating corticosteroids in chickens under stress, because decrease in vitamin $\mathrm{C}$ in the body tissues especially in renal and adrenal organs have been associated with corticosteroids release (Whitehead \& Keller 2003). Vitamin C depletion in the birds 
was prevented in the study by its exogenous supply prior to transportation of the birds. One of the most striking changes in clinical chemistries was detected for CPK. There was a decrease in value of all experimental groups with only vitamin $\mathrm{C}$ treated group being highly significant $(\mathrm{P}<0.01)$. This finding is not in agreement with that reported by Lumeij (1985), Kerr \& Snow (1983) and Alexandra et al. (2002) where after transportation in macaws, equine endurance rides and eventing, and poultry transportation and handling, AST and CPK activities were markedly increased. The result in this investigation may be due to the anti-oxidants activities of vitamins $\mathrm{C}$ and E treated groups and in addition to such factors as breed, genetic and individual variability of birds. The result observed in TP in our study is in agreement with that reported by Brown et al. (1999). The author noted that pigs subjected to $24 \mathrm{~h}$ road transportation suffered severe dehydration as the concentration of plasma TP and albumin were significantly increased. This result was similar to that observed in sheep (Knowles et al. 1996) and calves (Knowles et al. 1999). The AST showed a significant decrease in vitamin $\mathrm{E}$ treated group, this may be due to its ability to maintain the supply of egg precursors in plasma of laying hens (Bollengier-lee et al. 1998).

\section{CONCLUSION}

The results obtained in the present study for the first time showed the adverse effects of road transportation on the hematological parameter of layer hens, and the alleviating role of vitamins $\mathrm{C}$ and $\mathrm{E}$ on SBL transported by road during the hot dry season in the Guinea Savannah zone of Nigeria.

\section{REFERENCES}

Alexandra, S; T. Filip; G. Cornelia. \& E. Franziska. 2002. Influence of stress from transport and handling on hematologic and clinical chemistry blood parameters of racing pigeons (Columba livia domestica). Avian Disease, 46:224-229.

Benjamin, M.M. 1985. Outline of Veterinary Clinical Pathology. 3rd (eds). Kalyani, Publishers, New Delhi, India.

Bollengier-Lee, S; M.A. Mitchell; D.B. Utomo; P.E.V. Williams. \& C.C. Whitehead. 1998. Influence of high dietary vitamin E supplementation on egg production and plasma characteristics in hens subjected to heat stress. British Poultry Science, 39:106-112.

Brown, S.N; T.G. Knowles; J.E. Edwards. \& P.D. Warriss. 1999. Behavioral and Physiological responses of pigs to being transported for up to 24 hours followed by six hours recovery in lairage. Veterinary Record, 145:421-426.

Buvanendran, V. 1979. Development of national poultry foundation stocks. Pp. 144-162. In: (Olomu, et al. (eds). Poultry Production in Nigeria.

Ciftci, M; O. Nihat Ertas. \& T. Guler. 2005. Effects of vitamin E and vitamin C dietary supplementation on egg production and egg quality of laying hens exposed to a chronic heat stress. Revue Médecine Vétérinaire, 156 (Suppl II):107-111.

Delezie, E; Q. Swennen; J. Buyse. \& E. Decuypere. 2007. The effect of feed withdrawal and crating density in transit on metabolism and meat quality of broilers at slaughter weight. Poultry Science, 86:1414-1423. 
Donkoh, A. 1989. Ambient temperature: A factor affecting performance and physiological response of broiler chickens. International Journal of Biometeorology, 33:259-265.

Feldman, B.F; J.G. Zinkl. \& N.C. Jain. 2000. Schalms veterinary hematology 5th (Ed), Lippincott, Williams and Wilkins, Philadephia, USA; p. 21.

Hawkey, C; J.H. Samour; D.G. Ashton; M.G. Hart; R.N. Cindery; J.M. Finch. \& D.M. Jones. 1983. Normal and clinical hematology of captive cranks (Gruiforms). Avian Pathology, 12:73-84.

Holik, V. 2009. Management of laying hens to minimize heat stress. Lohmann Information, 44(1):1629.

Hollands, M. \& J.E. Logan. 1966. An examination of commercial kits for the determination of glutamic oxaloacetic transaminase (GOT) and glutamic pyruvic transaminase (GPT) in serum. Canadian Medical Association Journal, 95:303-306.

Igono, M.O; E.C.I. Molokwu. \& Y.O. Aliu. 1982. Body temperature responses of Savannah Brown goats to the harmattan and hot-dry season. International Journal of Biometeorology, 26:225-230.

Jain, N. C.1993. Essentials of Veterinary haematology. 4th (Ed), Lea and Febiger, Philadelphia, USA. Pp. 34-50.

Kerr, M.G. \& D.H. Snow. 1983. Equine Exercise Physiology. Pp. 432. In: D.H. Snow; S.G.B. Persson \& R.J. Rose (eds). Cambridge, Granta Editions.

Knowles, T.G; P.D. Warriss; S.N. Brown. \& J.E. Edwards. 1999. Effect on young calves of a onehour feeding stop during a 19-hour road journey. Veterinary Record, 144:692-695.

Knowles, T.G; R.C. Ball; P.D. Warriss. \& J.E. Edwards. 1996. A survey to investigate potential dehydration in slaughtered broiler chickens. British Veterinary Journal, 152:307-314.

Koelkebeck, K.W. \& J.R. Cain. 1984. Performance, behavior, plasma corticosterone, and economic returns of laying hens in several management alternatives. Poultry Science, 63:2123-2131.

Larkins, N.J. 1999. Free radical biology and pathology. Journal of Equine Veterinary Science, 19:8489.

Lumeij, J.T. 1985. Blood chemistry reference values in racing pigeons (Columba livia domestica). Avian Pathology, 14:401-408.

Minka, N.S. \& J.O. Ayo. 2008. Hematology and behavior of pullets transported by road and administered ascorbic acid during the hot-dry season. Research in Veterinary Science, 85:389-393.

Minka, N.S. \& J.O. Ayo. 2009. Physiological responses of food animals to road transportation stress: A review. African Journal of Biotechnology, 8 (25):7415-7427.

Minka, N.S. 2005. Effects of ascorbic acid on some physiological parameters of Red Sokoto Goats transported by road. Unpublished M.Sc. Thesis. Ahmadu Bello University, Zaria, Nigeria.

Mitchell, M.A. \& P.J. Kettlewell. 2009. Welfare of poultry during transport - a review. Poultry Welfare Symposium, Cervia, Italy. Pp. 90-100.

Nilipour, A.H. 2002. Poultry in transit are a cause for concern. World Poultry, 18 (2):30-33.

Oladele, S.B. \& J.O. Ayo. 1999. Comparative studies of hematocrit, hemoglobin and total protein values of apparently healthy and clinically sick indigenous chickens in Zaria, Nigeria. African Bulletin of Animal Health Production, 47:163-165.

Oladele, S.B; J.O. Ayo; S.O. Ogundipe. \& K.A.N. Esievo. 2005. Seasonal and sex variations in packed cell volume, hemoglobin and total protein of the guinea fowl (Numda meleagris) in Zaria, Northern Guinea Savannah zone of Nigeria. Journal of Tropical Biosciences, 5 (2):67-71.

Oyewale, J.O. \& J.L. Fajimi. 1988. The effects of egg-laying on hematological and plasma biochemistry of guinea hen. Bulletin of Animal Health and Production in Africa, 36:229-232.

Sahin, K; N. Sahin; M. Onderci; M.F. Gursu. \& M. Mustafa Issi. 2003. Vitamin C and E can alleviate negative effects of heat stress in Japanese quails. Food, Agriculture and Environment, 1 (2):244-49. 
Schalm, J.W; N.C. Jain. \& E.J. Carol. 1975. Veterinary hematology. 3rd (eds), Lea and Febriger. Philadelphia, USA. Pp. 15-81.

Selyansky, V.M. 1975. Microclimate in Poultry Houses. Kolos Publishing House, Moscow.

Singh, R. \& R. G. Sirisinghe. 2005. Hematological and plasma electrolyte changes after long distance running in high heat and humidity. Department of physiology, school of medical sciences, Universiti Sains Malaysia (Correspondence to: A/Prof. R. Singh), 1-5.

Vecerek, V; S. Grbalova; E. Voslarova; B. Janackova. \& M. Malena. 2006. Effects of travel distance and the season of the year on death rates in broilers transported to poultry processing plants. Poultry Science, 85:1881-1884.

Whitehead, C.C. \& T. Kettler. 2003. An update in ascorbic acid in poultry. World's Poultry Science Journal, 59:161-184.

Wilson, D.D. 2008. Manual of laboratory and diagnostic tests. McGraw-Hill companies, New York, USA. Pp. 439-440. 